\title{
DECISIONS RENDERED IN ABSENTIA AS A GROUND TO REFUSE THE EXECUTION OF A EUROPEAN ARREST WARRANT: EUROPEAN LEGAL STANDARDS AND IMPLEMENTATION IN CROATIAN LAW*
}

\author{
Elizabeta Ivičević Karas, PhD, Professor \\ University of Zagreb, Faculty of Law \\ Trg Republike Hrvatske 14, Zagreb, Croatia \\ elizabeta.karas.ivicevic@pravo.hr
}

\begin{abstract}
The right of a person charged with a criminal offence to appear and take part in a hearing is enshrined in the right to a fair trial in Article 6 of the European Convention on Human Rights and Fundamental Freedoms. A trial in absentia is allowed only exceptionally, and in the member states of the European Union it is traditionally regulated under very different legal regimes. This has been an obstacle to the full implementation of the principle of mutual recognition of final judicial decisions and therefore to efficient judicial cooperation in criminal matters. In order to provide clear common grounds allowing the execution of a European arrest warrant even when the person subject to it was absent at the trial, Framework Decision 2009/299/ JHA, amending Framework Decision 2002/584/JHA, defined the conditions under which a decision rendered at such a trial may be used as a ground to refuse the execution of a European arrest warrant. These conditions are the subject of this paper. Besides theoretical and normative analysis, the research includes the case law of the Court of Justice of the European Union, balancing between the efficiency of judicial cooperation and respect for fundamental human rights, as well as defining the notion of "the trial resulting in the decision" and specifying when the person was "summoned in person", or "by other means actually received official information of the scheduled date and place of that trial", since the right to take part in the trial may be waived. The research also includes an analysis of Croatian legislation and the jurisprudence of the Supreme Court of the Republic of Croatia in the same matter and an assessment of the implementation of European legal standards in Croatian law.
\end{abstract}

Keywords: European arrest warrant, trial in absentia, decision rendered in absentia, trial resulting in the decision, fair trial, mutual trust

This paper is the product of work that has been supported by the Croatian Science Foundation under project 8282 "Croatian Judicial Cooperation in Criminal Matters in the EU and the Region: Heritage of the Past and Challenges of the Future" (CoCoCrim) 


\section{INTRODUCTION: RIGHT TO BE PRESENT AT THE HEARING AS A FUNDAMENTAL ASPECT OF THE RIGHT TO A FAIR TRIAL}

The right of the accused to appear in person and take part in a hearing has been elaborated in the jurisprudence of the European Court of Human Rights (ECtHR) as one of the fundamental aspects of the right to a fair trial enshrined in Article 6 of the Convention for the Protection of Human Rights and Fundamental Freedoms (ECHR). ${ }^{1}$ It is also contained in Article 47(2) of the Charter of Fundamental Rights of the European Union, ${ }^{2}$ which proclaims the right to a fair trial in compliance with Article 6(1) ECHR. ${ }^{3}$ The presence of the defendant at the trial is considered "one of the fundamental premises of a fair trial", ${ }^{4}$ enabling him to use other important procedural rights, including defence rights. ${ }^{5}$

Despite its fundamental character, the right to be present at a hearing is not an absolute right. On one hand, the accused may waive his right to take part in the trial, either expressly or tacitly, but the waiver "must be established in an unequivocal manner and be attended by minimum safeguards commensurate to its importance" ${ }^{6}$ It is up to the state to prove that the accused willingly chose not to attend the trial. ${ }^{7}$ On the other hand, the absence of the accused from the hearing may be a result of force majeure, ${ }^{8}$ i.e. circumstances beyond his control. ${ }^{9}$ In either case, a trial in absentia may be justified with legitimate reasons and it may be in compliance with the requirements of a fair trial, as long as the accused is represented, i.e. defended with a defence counsel ${ }^{10}$ and has the possibility to request a

1 ECtHR, Sejdovic v. Italy, GC, 56581/00, 1 March 2006, par. 81; Colloza v. Italy, 9024/80, 12 February 1985, par. 29; Hermi v. Italy, 18114/02, 18 October 2006, par. 58

2 Charter of Fundamental Rights of the European Union [2000] OJEC C 364/1

3 And "the guarantees afforded by the ECHR apply in a similar way to the Union". Explanations relating to the Charter of Fundamental Rights [2007] OJ 2007 C 303/17, p. 30

4 Đurđević, Z., Rasprava, in: Kazneno procesno pravo Primjerovnik, Narodne novine, Zagreb, 2017

5 See Ivičević Karas, E., Reopening of Proceedings in Cases of Trial in absentia: European Legal Standards and Croatian Law, in: EU Law in Context - Adjustment to Membership and Challenges of the Enlargement, Osijek, 2018, p. 293

6 ECtHR, Sejdovic v. Italy, GC, 56581/00, 1 March 2006, par. 86; Colozza v. Italy, 9024/80, 12 February 1985 , par. 28

7 ECtHR, Sejdovic v. Italy, GC, 56581/00, 1 March 2006, par. 88; Colozza v. Italy, 9024/80, 12 February 1985 , par. 30

8 ECtHR, Colozza v. Italy, 9024/80, 12 February 1985, par. 30; Medenica v. Switzerland, 20491/92, 14 June 2001, par. 57

9 See Trechsel, S., Human Rights in Criminal Proceedings, Oxford University Press, 2005, p. 255

10 ECtHR, Sejdovic v. Italy, GC, 56581/00, 1 March 2006, par. 91 - 93; Krombach v. France, 29731/96, 13 February 2001, par. 84; Poitrimol v. France, 14032/88, 23 November 1993, par. 34 
retrial. ${ }^{11}$ Yet, due to the fundamental nature of the right of the accused to be present at the trial, some contemporary legal orders still do not allow trial in absentia, while others that consider it an exception to the rule that the accused is entitled to take part in the hearing ${ }^{12}$ do allow it, provided there are particular procedural guarantees. In other words, trials in absentia are still regulated under very different legal regimes, and the jurisprudence of the ECtHR obviously has not led to harmonization of the matter in national laws. ${ }^{13}$ This does not support mutual trust - a cornerstone of efficient judicial cooperation in criminal matters between member states of the European Union. The first problems already appeared in the early years of the application of the European arrest warrant. The following chapter will analyse how European institutions have attempted to resolve these problems.

\section{TRIAL IN ABSENTIA - AN OBSTACLE TO MUTUAL TRUST AND EFFICIENT JUDICIAL COOPERATION IN CRIMINAL MATTERS?}

\subsection{Problems in the early years of the European arrest warrant}

The European arrest warrant (EAW) was constructed on the idea of building an area of freedom, security and justice within the European Union. ${ }^{14}$ It was "the very first instrument" of judicial cooperation "that implemented the mutual recognition principle in the criminal law context" ${ }^{15}$ and there were great expectations of its effectiveness. Yet, from the perspective of mutual trust, judgments in absentia were viewed right at the beginning of the application of this new instrument as a "particularly difficult and controversial" issue. ${ }^{16}$

The Framework decision on the European arrest warrant and the surrender procedures between member states (FD 2002/584/JHA) ${ }^{17}$ originally provided the pos-

11 ECtHR, Sejdovic v. Italy, GC, 56581/00, 1 March 2006, par. 82, Medenica v. Switzerland, 20491/92, 14 June 2001, par. 54. See Trechesel. op. cit., note 9, p. 254

12 Ivičević Karas, op. cit., note 5, p. 292

13 Mauro, C., Le défaut criminel: Réflexions à propos du droit français et du droit comparé, Revue de science criminelle et de droit pénale comparé, Janvier/Mars 2006, p. 36

14 Plachta, M., European Arrest Warrant: Revolution in Extradition, 11 Eur. J. Crime Crim. L. \& Crim Just. 178, 2003, p. 179

15 Ouwerkerk, J., Balancing Mutual Trust and Fundamental Rights Protection in the Context of the European Arrest Warrant, European Journal of Crime, Criminal Law and Criminal Justice, Vol. 26, 2018, p. 103

16 See Plachta, op. cit., note 14, pp. 189-190.

17 Council Framework Decision of 13 June 2002 on the European arrest warrant and the surrender procedures between Member States (2002/584/JHA) [2002] OJ L 190/1 
sibility for the executing judicial authority to subject the surrender to the condition "that the issuing judicial authority gives an assurance deemed adequate to guarantee the person who is the subject of the European arrest warrant that he or she will have an opportunity to apply for a retrial of the case in the issuing Member State and to be present at the judgment" (Article 5(1) FD 2002/584/ JHA). In circumstances when there was a lack of the unique and clear concept of in absentia in member states, such a provision allowed quite a wide margin of discretion of the requested state to put a condition or even refuse the execution of an EAW in accordance with the standards of its own legal system. ${ }^{18}$ This did not contribute to strengthening the mutual trust and the realization of the principle of mutual recognition proclaimed in Article 82(1) of the Treaty on the Functioning of the European Union, ${ }^{19}$ even though the Court of Justice of the European Union (CJEU) has traditionally restrictively interpreted grounds for refusing the execution of an EAW in order to provide for the effectiveness of EU law through efficient judicial cooperation. ${ }^{20}$ On the other hand, the CJEU must should (at least) preserve the reached level of fundamental human rights protection in the jurisprudence of the ECtHR, but also at national levels. ${ }^{21}$ This actually required EU law to define and elaborate the (minimum) standards of trial in absentia which would, if the requesting state complied with them, exclude the possibility of the judicial authorities of the executing state refusing the execution of an EAW. This was done in 2009 through the amendment of FD 2002/584/JHA.

\subsection{Reducing the possibility of refusing the execution of an EAW}

Framework Decision 2009/299/JHA22 amended several framework decisions and introduced new provisions on "decisions rendered following a trial at which a person did not appear in person" (Article 4a) in FD 2002/584/JHA, which replaced the former provision of Article 5(1). This amendment specified admissible grounds for the refusal of the execution of an $\mathrm{EAW}^{23}$ and reduced the possibilities

18 Cavallone, G., European arrest warrant and fundamental rights in decisions rendered in absentia: the extent of Union law in the case C-399/11 Melloni v. Ministerio Fiscal, 4 Eur. Crim. L. Rev. 19, 2014, p. 29

19 Treaty on the Functioning of the European Union [2012] OJ O 326/47

20 See Millet, F-X., How Much Lenience for How Much Cooperation: On the First Preliminary Reference of the French Constitutional Council to the Court of Justice, 51 Common Market L. Rev. 195, 2014, p. 209

${ }_{21}$ The respect for fundamental human rights is proclaimed in the $12^{\text {th }}$ recital of the FD 2002/584 Preamble. See ibid., p. 210

22 Council Framework Decision 2009/299/JHA of 26 February 2009 amending Framework Decisions 2002/584/JHA, 2005/214/JHA, 2006/783/JHA, 2008/909/JHA and 2008/947/JHA, thereby enhancing the procedural rights of persons and fostering the application of the principle of mutual recognition to decisions rendered in the absence of the person concerned at the trial [2009] OJ L 81

23 Cavallone, op. cit. note 18 , p. 21 
for the member states to refuse the execution of an EAW when a national court complied with the new common rules on trial in absentia, which included the obligation of the state to ensure that the accused was informed of the trial, as well as the right of the accused to a new trial. ${ }^{24}$

After the amendment of FD 2002/584/JHA, the executing judicial authority may still refuse the execution of the EAW if the person did not appear in person at the trial resulting in the decision on a custodial sentence or a detention order, unless at least one of the procedural guarantees listed in Article 4a(1) has been respected. These four guarantees basically imply that: a) a person was summoned in person, or by other means actually informed of the scheduled trial, as well as informed that a decision may be handed down even in his/her absence; b) a person, being aware of the scheduled trial, took a legal counsel who indeed defended him/her at the trial; c) a person was served with the decision and was expressly informed of the right to a retrial or appeal, which may lead to the original decision being reversed, and the person expressly stated that he/she does not contest the decision, or did not request a retrial or appeal; or d) a person was not personally served with the decision, but will be served with it without delay after the surrender and will be informed of the right to a retrial, or an appeal, and of the timeframe to request it. If the requested person did not appear in the proceedings, and neither the information contained in the standard form for the EAW nor the information obtained pursuant to Article 15(2) FD 2002/584/JHA provided sufficient evidence on one of the situations listed in Article $4 \mathrm{a}(1)$ of the FD, the executing judicial authority is also entitled to refuse to execute the EAW. ${ }^{25}$

Even though the list of guarantees in Article $4 \mathrm{a}(1)$ tends to correspond to the additional safeguards required in cases of trial in absentia and defined in the jurisprudence of the ECtHR ${ }^{26}$ (see supra 1), they do not fully comply, which will be considered in the following chapters.

\section{FAVOURING THE EFFICIENCY OF JUDICIAL COOPERATION OVER RESPECT FOR FUNDAMENTAL HUMAN RIGHTS IN THE CASES OF TRIAL IN ABSENTIA?}

After the amendment of FD 2002/584/JHA, the CJEU was supposed to rely on the new provisions, which aimed to contribute to striking the right balance between the efficiency of judicial cooperation and the protection of fundamental

Klip, A., European Criminal Law, Intersentia, 2016, p. 282.

25 CJEU, C-271/17 PPU Slawomir Andrzej Zdziaszek, 10 August 2017, par. 109

26 See Cavallone, op. cit., note 18, p. 29 
rights in EAW cases concerning decisions rendered in absentia. Yet, it seems that initially the CJEU focused more on the efficiency of proceedings, particularly in the Melloni and Radu judgments. ${ }^{27}$

In the judgment Melloni, using literal interpretation, ${ }^{28}$ the CJEU specified that Article $4 \mathrm{a}(1)$ provides for a trial in absentia as an optional ground for the nonexecution of the EAW, which, though, is "accompanied by four exceptions in which the executing judicial authority may not refuse to execute the European arrest warrant in question". ${ }^{29}$ In this concrete case, Mr Melloni was informed of the trial and he was represented and effectively defended by two counsels that he appointed. ${ }^{30}$ These two guarantees alone were sufficient to eliminate the option to refuse the execution of the EAW. The CJEU clarified that this actually precluded any additional surrender condition, including the conviction rendered in absentia to be open to review in the issuing member state, in the presence of the convicted person. ${ }^{31}$ In other words, the CJEU actually specified that the list of grounds allowing the refusal of the execution of the EAW for Article $4 \mathrm{a}(1)$ is exhaustive, and the four guarantees are listed alternatively and not cumulatively. Yet, such reasoning is disputable from the perspective of the jurisprudence of the ECtHR. As Cavallone points out, it seems that the ECtHR requires both these requirements, the right to be represented by a lawyer and the possibility to claim a retrial, to be met cumulatively in order to comply with the right to fair trial guarantees ${ }^{32}$ (see also supra 1). Therefore, the scope of human rights protection in the execution of an EAW, in cases of trials in absentia, does not seem to fully comply with the guarantees provided in the jurisprudence of the ECtHR.

Looking from the human rights perspective, another problem is that Article $4 \mathrm{a}(1)$ does not cover all violations of fundamental human rights, nor the general duty to respect human rights, and therefore that a breach of fundamental rights as such cannot be a ground to refuse the execution of an EAW, which may be subject to justified criticism. ${ }^{33}$ Does this mean that the CJEU favours the efficiency of judi-

27 See Pajčić, M., Europski uhidbeni nalog u praksi Vrhovnog suda Republike Hrvatske, Hrvatski ljetopis za kaznene znanosti i praksu, vol. 24, no. 2, 2017, p. 576

28 CJEU, (Grand Chamber) C-399/11 Stefano Melloni v. Ministerio Fiscal, 26 February 2013, par. 41

29 Ibid., par. 40

30 See Cavallone, op. cit., note 18 , p. 30

31 CJEU, (Grand Chamber) C-399/11 Stefano Melloni v. Ministerio Fiscal, 26 February 2013, par. 40 and 46

32 Cavallone, op. cit., note 18 , p. 32

33 See van der Mei, A. P., The European Arrest Warrant system: Recent developments in the case law of the Court of Justice, Maastricht Journal of European and Comparative Law Vol. 24, No. 6, 2017, pp. 883 $-884$ 
cial cooperation over respect for fundamental human rights? The CJEU offered strong arguments supporting a positive response to this question.

In the Melloni judgment, the CJEU expressly stated, in general, that Article $4 \mathrm{a}(1)$ "is compatible with the requirements under Articles 47 and 48(2) of the Charter". ${ }^{34}$ Yet, when elaborating this standpoint, it stated that even when the standard of protection of fundamental rights guaranteed by the national constitution is higher than the one deriving from the Charter, the member state is not allowed "to make the surrender of a person convicted in absentia conditional upon the conviction being open to review in the issuing Member State, in order to avoid an adverse effect on the right to a fair trial and the rights of the defence guaranteed by its constitution". ${ }^{35}$ Thereby, the CJEU considers the principle of mutual recognition as an objective of constitutional value, which can then be balanced against fundamental rights protection, which is wrong, as Xanthopoulou expressly pointed out. ${ }^{36}$ The principle of mutual recognition is actually a regulatory method, and not an objective of constitutional value itself, and it should therefore not be balanced against fundamental rights protection. ${ }^{37}$

Another case where the CJEU seems to have given priority to the principle of mutual recognition over the protection of fundamental human rights was the Radu case. According to the judgment in Radu, the fact that the requested person was not heard in the issuing member state before the EAW was issued for the purposes of conducting a criminal procedure may not be a ground for the refusal of execution. ${ }^{38}$ The CJEU referred to the principle of mutual recognition, ${ }^{39}$ and pointed out that the objective of the FD was to accelerate judicial cooperation ${ }^{40}$ and that in principle the member states are "obliged to act upon a European Arrest Warrant". ${ }^{41}$ It stated that the fact that Mr Radu was not heard before the issuing judicial authorities issued the EAW does not fall within the grounds for non-execution listed in Article $4 \mathrm{a}(1) .{ }^{42}$ It concluded that Articles 47 and 48 of the Charter do not require "that a judicial authority of a Member State should be able to refuse to execute a European arrest warrant issued for the purposes of conduct-

\footnotetext{
34 CJEU, (Grand Chamber) C-399/11 Stefano Melloni v. Ministerio Fiscal, 26 February 2013, par. 54

35 Ibid., par. 64

36 Xanthopoulou, Ermioni, The Quest for Proportionality for the European Arrest Warrant: Fundamental Rights Protection in a Mutual Recognition Environment, 6 New J. Eur. Crim. L. 32, 2015, p. 46

37 Ibid., p. 46

38 CJEU, (Grand Chamber) C-396/11 Ciprian Vasile Radu, 29 January 2013, par. 43

39 Ibid., par. 33

$40 \quad$ Ibid., par. 34

$41 \quad$ Ibid., par. 35

$42 \quad$ Ibid., par. 38
} 
ing a criminal prosecution on the ground that the requested person was not heard by the issuing judicial authorities before that arrest warrant was issued", ${ }^{43}$ adding that "the right to be heard will be observed in the executing Member State in such a way as not to compromise the effectiveness of the European arrest warrant system" ${ }^{44}$

On one hand, it is possible to clearly distinguish the positions of the CJEU in the Melloni and in the Radu cases. Cavallone pointed out that in the Radu judgment the CJEU did not take such a strict approach as it did in Melloni, ${ }^{45}$ and similarly, Suominen held that the CJEU's attitude concerns only the right to be heard and not human rights aspects more generally. ${ }^{46}$ On the other hand, even though the CJEU did not explicitly exclude a breach of fundamental human rights as a ground for the refusal of the execution of the EAW in the Radu case, as it did in Melloni, it did give priority to the efficiency of the surrender system and mutual recognition over protection of the right to a fair trial, just as it did in the Meloni judgment. ${ }^{47}$ As Xanthopoulou stated, "the focus of the Court is the effectiveness of the surrender system", ${ }^{48}$ which should "facilitate and accelerate judicial cooperation with a view to contributing to the objective set for the European Union to become an area of freedom, security and justice...". ${ }^{49}$ Therefore, it is difficult to conclude that the CJEU reached the right balance between the efficiency of judicial cooperation and respect of fundamental human rights.

\section{RESTORING THE BALANCE}

It seems that, after the Radu and Melloni judgments, the CJEU focused on the interpretation of the "trial in absentia" concept within FD 2002/854/JHA. The amended Framework decision specifies guarantees under which the executing judicial authority may not refuse to execute the EAW, but it does not define the notion of "trial resulting in the decision". Knowing that different legal orders provide different situations when either a particular hearing, or the entire trial, may be held in the absence of the defendant, the concept of "trial resulting in the decision" under Article 4a(1) of FD 2002/854/JHA needed autonomous interpreta-

\footnotetext{
$43 \quad$ Ibid., par. 39

44 Ibid., par. 41

45 Cavallone, op. cit., note 18 , p. 30

46 Suominen, A., Limits of mutual recognition in cooperation in criminal matters within the EU-especially in light of recent judgments of both European Courts, 4 Eur. Crim. L. Rev. 210, 2014, p. 219

47 See Xanthopoulou, op. cit., note 36, pp. 45 and 39-40

48 Ibid., p. 40

49 CJEU, (Grand Chamber) C-399/11 Stefano Melloni v. Ministerio Fiscal, 26 February 2013, par. 37; and (Grand Chamber) C-396/11 Ciprian Vasile Radu, 29 January 2013, par. 34
} 
tion from the CJEU. The CJEU also interpreted the standard that the person was "summoned in person and thereby informed of the scheduled date and place of the trial which resulted in the decision".

\subsection{The concept of "trial resulting in the decision"}

In the judgment in Tupikas, ${ }^{50}$ the CJEU examined the scope of the "trial resulting in the decision". It had to clarify whether that term covers only first-instance proceedings, or also the appeal proceedings, and under what circumstances. In this case, the defendant was tried and sentenced in his presence, then appealed the judgment, but the appeal procedure did not result in an amendment of the sentence. The EAW did not reveal whether Mr Tupikas was present in the appeal proceedings. ${ }^{51}$ The Court of Justice, determining the scope of the concept of "trial resulting in the decision" stated that in such a case, when the criminal procedure involved several degrees of jurisdiction, which then may imply successive judicial decisions, "at least one of which has been handed down in absentia", the concept "must be interpreted as relating only to the instance at the end of which the decision is handed down which finally rules on the guilt of the person concerned and imposes a penalty on him, such as a custodial sentence, following a re-examination, in fact and in law, of the merits of the case". ${ }^{52}$ This means, on one hand, that the concept of a "trial resulting in the decision" applies to the appeal proceedings as well, implying that the person concerned must be in a position to fully exercise defence rights, ${ }^{53}$ as long as the court at that stage of the proceedings makes a final ruling on the person's guilt and imposes a penalty, after having re-examined the merits of the case, in fact and in law. In addition, such reasoning meant that a breach of defence rights in first-instance proceedings can actually be remedied at the appeal stage. ${ }^{54}$

In the $Z$ dziaszek judgment, the CJEU additionally elaborated criteria specified in the Tupikas judgment. In this case, Mr. Zdziaszek was not present in person in the proceedings in which the court decided to combine separate custodial sentences which had previously been imposed on him into one single custodial sentence. Interpreting the concept of a "trial resulting in the decision", the CJEU extended the scope of its application defined in the Tupikas judgment, specifying that "it must be interpreted as referring not only to proceedings which gave rise to the decision

\footnotetext{
50 CJEU, C-270/17 PPU Tadas Tupikas, 10 August 2017

51 Ibid., par. 29

52 Ibid., par. 98

53 Van der Mei, op. cit., note 33, p. 892

54 Ibid., p. 892
} 
on appeal, where that decision, after a fresh examination of the case on the merits, finally determined the guilt of the person concerned, but also to subsequent proceedings, such as those which led to the judgment handing down the cumulative sentence at issue here, at the end of which the decision that finally amended the level of the initial sentence was handed down, inasmuch as the authority which adopted the latter decision enjoyed a certain discretion in that regard". ${ }^{55}$ The CJEU held that such proceedings "determine the quantum of the sentence", and therefore the person concerned must be able to exercise defence rights and influence the respective decision. ${ }^{56}$

It is possible to conclude from Tupikas and Zdziaszek that in order to be able to execute the EAW, it is required for the requested person to have been present in the proceedings which gave rise to the decision which finally determined the guilt, as well as in the proceedings where the final sentence was determined, proceedings which do not necessarily coincide. ${ }^{57}$ It seems that the focus of the CJEU was on fair trial rights, which contributed to restoring the balance with the requirement of the efficiency of judicial cooperation.

The CJEU provided a further interpretation of a "trial resulting in the decision" in the Ardic case. Mr Ardic was present in person in criminal proceedings that resulted in judgments imposing on him two custodial sentences, but the subsequent suspension revocation decisions were handed down in absentia. ${ }^{58}$ The CJEU considered whether a decision to revoke the suspension of execution of a custodial sentence previously imposed should be qualified as a judicial decision that finally amended the level of one or several previous sentences, in the sense that it definitely ruled on the guilt of the person and the custodial sentence imposed on him, where relevant, after assessing the case in fact and in law. ${ }^{59}$ Relying on the jurisprudence of the ECtHR, the CJEU found that the decisions to revoke the suspension of the execution of previously imposed custodial sentences "did not affect the nature or the quantum of custodial sentences imposed by final conviction judgments of the person concerned, which form the basis of the European arrest warrant" ${ }^{60}$ Therefore the concept of a "trial resulting in the decision" does not include "subsequent proceedings in which that suspension is revoked on the grounds of infringement of those conditions during the probationary period, pro-

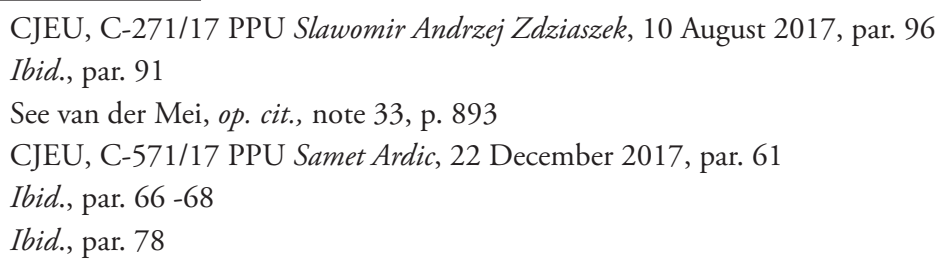


vided that the revocation decision adopted at the end of those proceedings does not change the nature or the level of the sentence initially imposed". ${ }^{61}$

\subsection{The requirement that a person be summoned or/and informed of the scheduled date and place of a trial which resulted in a decision}

Another guarantee, excluding the possibility to refuse the execution of an EAW which required autonomous interpretation, was the requirement that a requested person be "in due time summoned in person and thereby informed of the scheduled date and place of the trial which resulted in the decision" or alternatively "by other means actually received official information of the scheduled date and place of that trial in such a manner that it was unequivocally established that he or she was aware of the scheduled trial" (Article 4a(1)(a)(i) FD 2002/584/JHA). If that requirement is complied with, and if, in addition, the requested person was informed that a decision may be handed down even in the case of his/her absence from the trial (Article 4a(1)(a)(ii) FD 2002/584/JHA), the EAW must be executed, despite the trial in absentia.

In the Dworzecki case, the CJEU interpreted these two criteria. In this case, $\mathrm{Mr}$. Dworzecki was absent from the trial leading to the judgment imposing a sentence. He was not summoned in person and therefore informed of the trial, but the summons was served on his grandfather, being an adult resident of the addressee's household. ${ }^{62}$ The problem is that it could not be determined, from the EAW, whether his grandfather actually passed that summons on to Mr. Dworzecki. ${ }^{63}$ In such a case, "the issuing judicial authority must provide evidence showing that the person concerned was actually aware of that information". ${ }^{64}$ So if a summons was not served directly on the person concerned, but on an adult resident of the same household who undertook to pass it on to the person concerned, and if it cannot be ascertained from the EAW if and when that adult really passed the summons on, the conditions set out in Article 4a(1)(a)(i) FD 2002/584 are not satisfied, ${ }^{65}$ which means that it is allowed for the executing authority to refuse the execution of the EAW if none of the other three guarantees from Article 4a(1) has been complied with.

As Ouwerkerk points out, the judgment in the Dworzecki case "primarily deals with the interpretation of technical-legal terms" from the EAW Framework Deci-

\footnotetext{
$61 \quad$ Ibid., par. 92

62 CJEU, C-108/16 PPU Pawel Dworzecki, 24 May 2016, par. 12

63 Ibid., par. 33

64 Ibid., par. 41

65 Ibid., par. 54
} 
sion. ${ }^{66}$ The CJEU indeed repeatedly pointed out that the purpose of the FD 2009 was not to harmonize trial in absentia in member states in general, "but only to lay down common grounds for refusal as regards judgments delivered in absentia in criminal matters" ${ }^{67}$ Yet, even though the CJEU did not consider the fair trial guarantees as such, it made clear that the right to information must be real and effective, in order to comply with the protection of fair trial guarantees.

\section{IMPLEMENTATION IN CROATIAN LAW}

The Croatian legislator transposed the provisions of Article 4a(1) FD 2002/584/ JHA into the Act on Judicial Cooperation in Criminal Matters with Member States of the European Union (AJCCM) ${ }^{68}$ Article 21(2) AJCCM regulates that the court may refuse the execution of the EAW if the person was absent from a trial resulting in a decision on a custodial sentence or a detention order, ${ }^{69}$ unless four listed procedural guarantees have been respected, which must derive from the information given in the EAW. When the surrender is requested for the purpose of conducting criminal proceedings, and not to execute a final sentence, the trial in absentia may not be invoked as a ground to refuse the execution of the EAW. ${ }^{70}$

The risk of violation of fundamental human rights is not provided as a ground to refuse the execution of an EAW, ${ }^{71}$ which has been criticized in the literature, ${ }^{72}$ even though the AJCMM does proclaim the principle of respect of fundamental human rights (Article 3.a AJCMM), just like the principle of mutual recognition between member states (Article 3 AJCCM). The criticism is justified, since Croatian criminal procedure law does provide strong fair trial safeguards in cases of trial in absentia: mandatory defence, i.e. mandatory representation by a defence

66 Ouwerkerk, op. cit., note 15, p. 103

67 CJEU, C-108/16 PPU Pawel Dworzecki, 24 May 2016, par. 14. Similarly, in CJEU, (Grand Chamber) C-399/11 Stefano Melloni v. Ministerio Fiscal, 26 February 2013, par. 43

68 Zakon o pravosudnoj suradnji s državama članicama Europske unije, Official Gazette 91/2010, $81 / 2013,124 / 2013,26 / 2015,102 / 2017,68 / 2018$

69 If the decision to revoke the suspension of the execution of a previously imposed custodial sentence, because the convicted person committed another criminal offence during the probation period, was brought in absentia, but the convicted person was obviously informed of the decision revoking the suspended sentence, since he opposed the execution of the prison sentence, according to the Supreme Court of the Republic of Croatia, there is no ground for the refusal of the execution of the EAW. VSRH, Kž-eun 26/2018-4, 28 August 2018. It is interesting that the Supreme Court made no reference to the judgment of the CJEU in Ardic (see supra 4.1)

70 VSRH, Kž-eun 14/13-4, 24 October 2013

71 Unlike some member states of the European Union, see Čule, J.; Hržina, D., Primjena europskog uhidbenog naloga u Republici Hrvatskoj - očekivanja i stvarnost, Hrvatski ljetopis za kazneno pravo i praksu, Vol. 20, no. 2, 2013, p. 723

72 See Pajčić, op. cit., note 27, p. 573 
counsel, as well as the right to claim an "automatic" reopening of proceedings that have ended with a final judgment. ${ }^{73}$

The four procedural guarantees under Article 21(2)1-4 AJCCM comply with those listed in Article 4a(1) FD 2002/584/JHA, yet from the legislative phrasing it is not completely clear whether those guarantees are listed alternatively or cumulatively. It could be understood that they are listed cumulatively, since there is no conjunction "or" between each of the four guarantees. Yet, the Supreme Court of the Republic of Croatia ${ }^{74}$ clarified that these four guarantees do not have to be cumulatively fulfilled, since "it is sufficient to meet certain of these assumptions" that the court considers to be appropriate to provide the requested person with a fair trial and respect of fundamental rights and freedoms guaranteed by the ECHR, in the requesting country and according to its law. ${ }^{75}$ In the concrete case, the Supreme Court concluded that this requirement was fulfilled since, as the EAW stated, the requested person would have the right to request a retrial, and in addition, he was summoned in person or by other means informed of the date and the place of the trial held in absentia. ${ }^{76}$ In another case, the requested person was represented by a defence counsel during the proceedings in absentia, he authorised the defence counsel to receive documents, and therefore the Supreme Court concluded that he was aware of the proceedings and informed through the counsel that the trial, if he did not appear, may be conducted in his absence. ${ }^{77}$ The Supreme Court concluded that these circumstances excluded any reason allowing refusal of the execution of the EAW. ${ }^{78}$ The jurisprudence of the Supreme Court provided additional clear confirmation that the requirements under Article 21(2) AJCCM are listed alternatively, stating that even though, in the concrete case, the requested person was tried in absentia and was not informed of the scheduled date and place of the trial, and was not informed that he may be tried in absentia if he did not appear at the trial, it was sufficient that the requesting state provided a guarantee that the requested person would have the right to claim a retrial, according to Article 21(2) 4 AJCCM. ${ }^{79}$

Even when the EAW provided information that the requested person was "in the other way officially informed of the scheduled time and place of the hearing

\footnotetext{
73 In more detail, see Ivičević Karas, op. cit., note 5, p. 297 ff.

${ }^{74}$ The Supreme Court of the Republic of Croatia decides on appeals against first-instance decisions of county courts on surrender based on the EAW

75 VSRH, Kž-eun 28/14-4, 4 July 2014

76 Ibid.

77 VSRH, Kž-eun-15/2017-4, 26 April 2017

78 Ibid.

79 VSRH, Kž-eun 37/16-4, 19 October 2016
} 
that resulted in the decision", the Supreme Court still instructed the first-instance county court to remove doubts on whether the person was really informed of the proceedings conducted in absentia, and also whether he was represented by a defence counsel, in order to bring a new decision. ${ }^{80}$ Still, this should not lead to the conclusion that the Supreme Court would demand both requirements to be complied with cumulatively, but rather that the Supreme Court insists that the issued EAW should contain clear and precise information relevant for deciding on the surrender. If the EAW does not show clearly whether a requested person was tried in his/her presence or in absentia, the Supreme Court orders a repeating of the proceedings before the county court, with the instruction to collect information whether the trial was held in absentia and, if it was, the information requested in Article 21(2) 1-4 AJCCM. ${ }^{81}$ If neither the EAW nor additionally requested information provides sufficient evidence that any of the guarantees under Article 21(2) AJCCM was complied with, the first-instance court should refuse the execution of the EAW (see the Zdziaszek judgment, supra 2.2). In addition, there has to be a good quality translation of the EAW in the Croatian language, so that the firstinstance court can verify whether the guarantees for Article 21(2) points 1-4 are fulfilled, before bringing a lawful and reasoned decision on the EAW. ${ }^{82}$

\section{CONCLUDING REMARKS}

It is possible to conclude that Croatia has so far implemented common grounds from FD 2002/584/JHA for a refusal to execute an EAW as regards judgments delivered in absentia. The risk of violation of fundamental human rights is not prescribed as a ground to refuse the execution of an EAW. Still, respect for fundamental human rights, including the right to a fair trial, is proclaimed as a principle of judicial cooperation. The Supreme Court adjudicates in line with FD 2002/584/ JHA and the jurisprudence of the CJEU, yet it shows particular attention to the protection of the right to a fair trial. In one case before the Supreme Court, the requested person appealed against a decision on surrender, on the ground that the judgment of the Italian court, the imposition of fifteen years of imprisonment, was the result of trials conducted in absentia. The Supreme Court stated that "even though the requested person did not attend the hearing at which the judgment was issued", he was informed of the scheduled hearing and authorised legal representatives (two lawyers from Verona) who effectively represented him during the hearing. ${ }^{83}$ Therefore, there were no grounds to justify the refusal of the execution

\footnotetext{
80 VSRH, Kž-eun 18/2018-4, 18 July 2018. Similarly, in VSRH, Kž-eun 6/2019-4, 20 February 2019

81 VSRH, Kž-eun 34/2018-4, 30 October 2018

82 VSRH, Kž-eun 23/14-4, 30 May 2014

83 VSRH, Kž-eun 5/15-5, 11 February 2015
} 
of the EAW due to trial in absentia. Still, the Supreme Court has considered allegations of violations of the right to a fair trial in proceedings which resulted in a judgment in absentia, with reference to the jurisprudence of the ECtHR. The Supreme Court first explained that only a risk of the flagrant denial of a fair trial may be a ground to refuse extradition, and it is up to the requested person who appealed to provide a reason to believe that such a risk exists. ${ }^{84}$ An evaluation of evidence, presented by the requested person, as such, did not lead to the conclusion, in the Supreme Courts' opinion, that he was denied the right to a fair trial under Article 6(1) ECHR in proceedings that resulted in a judgment in absentia. ${ }^{85}$ Even if the Supreme Court referred to extradition, and not specifically to the EAW, and it did not explicitly state that the flagrant denial of a fair trial might be a ground to refuse the execution of the EAW, it actually stressed the importance of the right to a fair trial in general, as it did in some other cases. ${ }^{86}$ It implicitly indicated that the right to a fair trial should not be outweighed by the tendency to provide efficient judicial cooperation. It remains to be seen how the jurisprudence of the CJEU will further balance between the two tendencies, to what extent it will comply with the ECtHR case law regarding trial in absentia, and how the Supreme Court of the Republic of Croatia will continue implementing European legal standards.

\section{REFERENCES}

\section{BOOKS AND ARTICLES}

1. Cavallone, G., European arrest warrant and fundamental rights in decisions rendered in absentia: the extent of Union law in the case C-399/11 Melloni v. Ministerio Fiscal, 4 Eur. Crim. L. Rev. 19, 2014, pp. 19-40

2. Čule, J.; Hržina, D., Primjena europskog ubidbenog naloga u Republici Hrvatskoj - očekivanja i stvarnost, Hrvatski ljetopis za kazneno pravo i praksu, Vol. 20, no. 2, 2013, pp. 715-750

3. Đurđević, Z., Rasprava, in: Kazneno procesno pravo Primjerovnik, Narodne novine, Zagreb, 2017

4. Ivičević Karas, E., Reopening of Proceedings in Cases of Trial in absentia: European Legal Standards and Croatian Law, in: EU Law in Context - Adjustment to Membership and Challenges of the Enlargement, Osijek, 2018, pp. 291-309

5. Klip, A., European Criminal Law, Intersentia, 2016

6. Mauro, C., Le défaut criminel: Réflexions à propos du droit français et du droit comparé, Revue de science criminelle et de droit pénale comparé, Janvier/Mars 2006, p. 35-48

\footnotetext{
84 Ibid.

85 Ibid.

86 See other examples of cases where the Supreme Court considered risks to the violation of the right to a fair trial in Pajčić, op. cit., note 27, pp. $574-575$
} 
7. Millet, F-X., How Much Lenience for How Much Cooperation: On the First Preliminary Reference of the French Constitutional Council to the Court of Justice, 51 Common Market L. Rev. 195, 2014, pp. 195-218

8. Ouwerkerk, J., Balancing Mutual Trust and Fundamental Rights Protection in the Context of the European Arrest Warrant, European Journal of Crime, Criminal Law and Criminal Justice Vol. 26, 2018, pp. 103-109

9. Pajčić, M., Europski uhidbeni nalog u praksi Vrhovnog suda Republike Hrvatske, Hrvatski ljetopis za kaznene znanosti i praksu, Vol. 24, No. 2, 2017, pp. 553-581

10. Plachta, M., European Arrest Warrant: Revolution in Extradition, 11 Eur. J. Crime Crim. L. \& Crim Just. 178, 2003, pp. 178-194

11. Suominen, A., Limits of mutual recognition in cooperation in criminal matters within the EU - especially in light of recent judgments of both European Courts, 4 Eur. Crim. L. Rev. 210, 2014, pp. 210-235

12. Trechsel, S., Human Rights in Criminal Proceedings, Oxford University Press, 2005

13. van der Mei, A. P., The European Arrest Warrant system: Recent developments in the case law of the Court of Justice, Maastricht Journal of European and Comparative Law, Vol. 24, No. 6, 2017, pp. 882-904

14. Xanthopoulou, Ermioni, The Quest for Proportionality for the European Arrest Warrant: Fundamental Rights Protection in a Mutual Recognition Environment, 6 New J. Eur. Crim. L. 32, 2015, pp. 32-52

\section{DECISIONS OF THE EUROPEAN COURT OF HUMAN RIGHTS}

1. ECtHR, Colloza v. Italy, 9024/80, 12 February 1985

2. ECtHR, Hermi v. Italy, 18114/02, 18 October 2006

3. ECtHR, Krombach v. France, 29731/96, 13 February 2001

4. ECtHR, Medenica v. Switzerland, 20491/92, 14 June 2001

5. ECtHR, Poitrimol v. France, 14032/88, 23 November 1993

6. ECtHR, Sejdovic v. Italy, GC, 56581/00, 1 March 2006

\section{EU LAW}

1. Charter of Fundamental Rights of the European Union [2000] OJEC C 364/1

2. Council Framework Decision 2009/299/JHA of 26 February 2009 amending Framework Decisions 2002/584/JHA, 2005/214/JHA, 2006/783/JHA, 2008/909/JHA and 2008/947/ JHA, thereby enhancing the procedural rights of persons and fostering the application of the principle of mutual recognition to decisions rendered in the absence of the person concerned at the trial [2009] OJ L 81

3. Council Framework Decision of 13 June 2002 on the European arrest warrant and the surrender procedures between Member States (2002/584/JHA) [2002] OJ L 190/1

4. Explanations relating to the Charter of Fundamental Rights [2007] OJ 2007 C 303/17

5. Treaty on the Functioning of the European Union [2012] OJ O 326/47 


\section{JUDGMENTS OF THE COURT OF JUSTICE OF THE EUROPEAN UNION}

1. CJEU, C-571/17 PPU Samet Ardic, 22 December 2017

2. CJEU, C-108/16 PPU Pawel Dworzecki, 24 May 2016

3. CJEU, (Grand Chamber) C-399/11 Stefano Melloni v. Ministerio Fiscal, 26 February 2013

4. CJEU, (Grand Chamber) C-396/11 Ciprian Vasile Radu, 29 January 2013

5. CJEU, C-270/17 PPU Tadas Tupikas, 10 August 2017

6. CJEU, C-271/17 PPU Slawomir Andrzej Zdziaszek, 10 August 2017

\section{LIST OF NATIONAL REGULATIONS}

1. Zakon o pravosudnoj suradnji s državama članicama Europske unije, Official Gazette $91 / 2010,81 / 2013,124 / 2013,26 / 2015,102 / 2017,68 / 2018$

\section{DECISIONS OF THE SUPREME COURT OF THE REPUBLIC OF CROATIA}

1. VSRH, Kž-eun 6/2019-4, 20 February 2019

2. VSRH, Kž-eun 34/2018-4, 30 October 2018

3. VSRH, Kž-eun 26/2018-4, 28 August 2018

4. VSRH, Kž-eun 18/2018-4, 18 July 2018

5. VSRH, Kž-eun-15/2017-4, 26 April 2017

6. VSRH, Kž-eun 37/16-4, 19 October 2016

7. VSRH, Kž-eun 5/15-5, 11 February 2015

8. VSRH, Kž-eun 28/14-4, 4 July 2014

9. VSRH, Kž-eun 23/14-4, 30 May 2014

10. VSRH, Kž-eun 14/13-4, 24 October 2013 